\title{
IQTISHODUNA
}

IQTISHODUNA: Jurnal Ekonomi Islam

E-ISSN: 2443-0056, P-ISSN: 2252-5661

Accredited Sinta 2 Number 148/M/KPT/2020

Volume 10 Issue 1, April 2021 | Page: 017-034

DOI: $\underline{\text { doi.org/10.36835/iqtishoduna.v10i1.729 }}$

\section{The Effect of Islamic Financing Schemes on Risk and Financing Performance in Islamic Banks in Indonesia}

\author{
Ahmad Roziq ${ }^{*}$, Hari Sukarno ${ }^{2}$ \\ ${ }^{1}$ Departement of Accounting, Faculty of Economics and Business, Universitas Jember, \\ Jl. Kalimantan 37 Kampus Bumi Tegal Boto Kotak Pos 159 Jember 68121, Indonesia \\ ${ }^{2}$ Departement of Management Faculty of Economics and Business, Universitas Jember, \\ Jl. Kalimantan 37 Kampus Bumi Tegal Boto Kotak Pos 159 Jember 68121, Indonesia
}

\begin{abstract}
The purpose of this study is to prove the effect of the financing scheme on financing risk and financing performance in Islamic banks in Indonesia. This research applies a form of quantitative research with the type of explanatory research that aims to accept or reject hypotheses. The population in this study are Islamic banks in Indonesia. The data used in the study are secondary data in the form of financial ratios sourced from Islamic bank financial reports for 2015 to 2019. Data analysis techniques use partial least squares which are used to test the inner model and outer model. The results of the study found that the sharia financing scheme that uses the buying and selling system and the profit sharing system has a significant effect on the risk of financing. However, the sharia financing scheme that uses the lease system has no significant effect on financing risk. The results also found that financing risk has a significant effect on the performance of Islamic bank financing in Indonesia. The results showed that the management of Islamic banks must be able to manage buying and selling financing and profit-sharing and profit-sharing financing schemes carefully and minimizing the risk of financing.
\end{abstract}

Keywords: Islamic financing schemes, risk, performance

Article History:

Received: November 6, 2020; Accepted: March 7, 2021; Published:

April 1, 2021

*Corresponding author: e-mail ahmadroziq.feb@unej.ac.id

Paper type: Research paper

Cite this document: Roziq, Ahmad, AND Sukarno, Hari. "The Effect of Islamic Financing Schemes on Risk and Financing Performance in Islamic Banks in Indonesia" IQTISHODUNA: Jurnal Ekonomi Islam [Online], Volume 10 Number 1 (April 1, 2021)

Abstrak: Tujuan penelitian ini adalah untuk mengetahui, menguji, dan membuktikan pengaruh skema pembiayaan terhadap risiko pembiayaan dan kinerja pembiayaan pada bank syariah di Indonesia. Penelitian ini menerapkan bentuk penelitian kuantitatif dengan jenis penelitian eksplanatori yang bertujuan untuk menjelaskan, menguji, atau membuktikan suatu teori atau hipotesis untuk menerima atau menolak teori atau hipotesis hasil penelitian yang ada. Populasi dalam penelitian ini adalah bank syariah di Indonesia. Data yang digunakan dalam penelitian adalah data sekunder berupa rasio keuangan yang bersumber dari laporan keuangan bank syariah tahun 2015 s/d 2019. Tehnik analisis data menggunakan partial least square yang digunakan untuk menguji inner model dan outer model. Hasil penelitian menemukan bahwa skema pembiayaan syariah yang menggunakan sistem jual beli dan sistem bagi hasil berpengaruh signifikan terhadap risiko pembiayaan. Namun skema pembiayaan syariah yang menggunakan sistem lease tidak berpengaruh signifikan terhadap risiko pembiayaan. Hasil penelitian juga menemukan bahwa risiko pembiayaan berpengaruh signifikan terhadap kinerja pembiayaan bank 
syariah di Indonesia. Hasil penelitian menunjukkan bahwa manajemen bank syariah harus mampu mengelola pembiayaan jual beli dan skema pembiayaan bagi hasil dan bagi hasil dengan hati-hati serta dapat meminimalkan risiko pembiayaan. Kemampuan manajemen bank syariah dalam mengelola dan meminimalkan risiko pembiayaan akan mampu meningkatkan kinerja pembiayaan bank syariah di Indonesia.

Kata kunci: skema pembiayaan Islam, resiko, kinerja.

\section{INTRODUCTION}

Based on data from the Financial Services Authority in 2019 there were 202 Islamic financial institutions consisting of 14 Islamic banks, 20 Islamic bank business units, and 168 Islamic people's credit banks. The amount is quite good, then increase the quantity of Islamic banking should be able to contribute to society. However, problems that still occur such as low public welfare, unstable company performance, the risk of default, and so forth. If calculated the age level of the emergence of Islamic banks starting in 1992 until now has reached 28 years, but the performance of Islamic banks is still relatively weak. Febrianti \& Ashar argues that the principles of Islamic banks can dominate the role of Islamic banks in the future. ${ }^{1}$ In granting credit, Islamic banks are superior and consistent in maintaining trust because Islamic businesses tend to prioritize customer needs. However, there are weak points in Islamic banks because the unstable financial condition results in a weak system

\footnotetext{
${ }^{1}$ Febrianti, S. E., \& Ashar, K. (2016). Analysis of the Influence of GDP Growth, Inflation, BI Rate and Exchange Rate of NonPerforming Loans at Conventional Banks and Islamic Bank. FEB Student Scientific Journal, $3(2)$.
}

and causes various risks. Roziq revealed that increasing the performance of financing based on profit-loss sharing means it will also increase the magnitude of the role of accounting in the implementation of profit-based financing and will return the operational system of Islamic banking to the actual system, ${ }^{2}$ namely banks with equitable profit-sharing systems so will have a positive and beneficial impact on Islamic banks, stakeholders, and society. Islamic banking with a good level of financing performance is certainly inseparable from the risks to be faced. From the perspective of Islamic banks, the risk of financing itself can generally be understood as a risk of failure or inability of customers to repay loans/financing received from banks in accordance with the specified time period. ${ }^{3}$ This risk if the solution is not immediately sought can continue continuously and can adversely affect the financial health of Islamic

\footnotetext{
${ }^{2}$ Ahmad Roziq, The Effect of Islamic Business Ethics on the Performance of Mudharabah Financing through Asymmetrical Information on Islamic Banks in East Java. JEAM, IX(1), (2010) 56-69.

${ }^{3}$ Kurnia, R. A. E., Sawarjuwono, T. \& Herianingrum, S, Financing risk management to anticipate financial distress conditions in Islamic banks, Journal of Islamic Economics Lariba, (2017)3(2), 51-64.
}

18| Copyright (C 2021, IQTISHODUNA: Jurnal Ekonomi Islam http://ejournal.iaisyarifuddin.ac.id/index.php/iqtishoduna 
banks, resulting in the bank will experience an event called financial distress or bankruptcy. In distributing risk, Islamic banks offer a concept that is a profit-sharing system known as profit and loss sharing (PLS). In theory, the profit and loss sharing system have implications for risks that should also be able to help Islamic banks be more stable in dealing with moral hazard, especially in financing. Islamic bank operational activities certainly cannot be separated from the risk of financing problems.

Revealed that in the banking sector activities cannot be separated from existing risks, ${ }^{4}$ so an effort is needed to deal with risks so that banks can survive in business competition.

Islamic banks set a strategy to minimize the occurrence of risks as measured by NPF so as not to be in a condition that is too worrying. The NPF ratio of Islamic banks tends to move faster and relatively high so that it can result in a vulnerable financial performance weakening. Managing risk, anticipating risk, and figuring out what will be caused by risk is a must in efforts to maintain the existence of financing products, one of which is Murabaha, which has experienced a significant increase compared to other products. The potential possessed by Murabaha products is

${ }^{4}$ Dayu, P. Q. Effect of capital adequacy level, liquidity, market risk, and credit risk on financial performance in conventional banks. EJurnal Universitas Negeri Padang, (2015), 1-15. maintained as an effort to minimize risks in maintaining public trust. ${ }^{5}$ Research conducted by Harahap found that there was a positive influence of Murabaha financing on financing risk. ${ }^{6}$ The amount of risk arising from Murabaha financing can have an impact on company losses. When Murabaha financing is now superior to other financings, there will be a variety of risks that occur. Research conducted by Amalia proves that mudaraba financing and musharaka financing affect financing risk. Profit-sharing financing is classified as financing that has a high level of risk because Islamic banks cannot recover funds that have been distributed to mudarib. ${ }^{7}$ The high risk of financing will also have an impact on the performance of banks in obtaining profits and lost opportunities to obtain revenue. Funding channeled by Islamic banks is very possible to contain risks, one of which is nonperforming finance. The results of some of these studies explain the

\footnotetext{
${ }^{5}$ Harahap, A. S., \& Siregar, S, Operational risk of islamic banking murabahah financing. National Seminar on Computer Technology and Science,(2020) 561-567.

${ }^{6}$ Harahap, A. S., \& Siregar, S, Operational risk of islamic banking murabahah financing. National Seminar on Computer Technology and Science,(2020) 561-567

${ }^{7}$ Amalia, S., \& Hapsari, A. A., Credit risk analysis based on mudharabah and musyarakah profit sharing funds based on profitability (ROA) of sharia foreign exchange commercial banks per quarter (2016-2017 period). ISEI Accounting Review, I (1), (2009), 32-38.
} 
influence of Islamic financing on financing risk.

Islamic banks in Indonesia in optimizing the performance of Islamic banks, the management of Islamic Banks must control problem financing (NPF). The lower the NPF, the better the performance of the financing undertaken. ${ }^{8}$ The high assets of Islamic banks provide an opportunity for increased nonperforming financing (NPF). ${ }^{9}$ Mukhibad and Khafid's research proves that NPF is influenced by financing. Higher NPF is influenced by Islamic bank assets and funding. But on the contrary, research conducted by Djatmiko and Rachman obtained the results of simultaneous testing of murabaha and mudharaba financing which had no significant effect on nonperforming financing (NPF). ${ }^{10}$ Hafidh revealed that the nature of mudharaba financing is productive. ${ }^{11}$ Mudharaba financing

\footnotetext{
${ }^{8}$ Sagantha, F, Reviewing the performance of Islamic banks in Indonesia. Scientific Journal Of Reflection, 3(1), (2020), 31-40. doi: 10.5281/zenodo.3597840.

${ }^{9}$ Mukhibad, H. \& Khafid, M, Article history: Financial Performance Determinant of Islamic Banking in Indonesia. Journal of Finance, (2018).

${ }^{10}$ Rachman, D, Effect of Mudharabah and Murabahah Financing on Non-Performing Financing (NPF) (Case Study of Sharia Commercial Banks in Indonesia). Study and Accounting research, XII(1), (2015), 19-38.

${ }^{11}$ Hafidh, A. A, Analisis hubungan pengeluaran pendidikan dan pertumbuhan ekonomi dengan menggunakan pendekatan kausalitas granger. Journal of Economics \& Education, (8 November 2011), pp. 124-141.
}

can be used to provide working capital by empowering economic activities, especially the lower middle class by developing businesses, increasing people's income, and reducing poverty and unemployment. Waldelmi proves that buying and selling financing and profit-sharing have a significant effect on customer trends in Islamic banks. ${ }^{12}$ This shows that Islamic banking financing can affect the interests of the community and will contribute positively. Islamic Bank gives goods/services contracts to the customer, then the customer will manage the leased appropriately. If the customer can manage it well, it will minimize the risks that occur and the damage caused is relatively small. Lease financing can be identified through risk monitoring and control. The greater the lease financing carried out, it increases the viability of the bank's operations but must also control the level of risk so that there is no huge loss. Islamic banks need to consider the risk of rental finance failures in meeting installment or asset payment obligations to customers. ${ }^{13}$ The risk in the lease contract is the inability of the customer to pay large installments at the end of the

\footnotetext{
${ }^{12}$ Waldelmi, I. \& Masirun, Analysis of factors affecting consumer's behavior on syariah Banking Products. IOP Conference Series: Earth and Environmental Science, (2018), 175(1).

${ }^{13}$ Farida \& Dewi, F, The analysis of risk management on syariah banking in indonesia. Seminar Nasional dan The 3rd Call for Syariah Paper. 1,(2016), 164-174.
} 
period due to the swelling of the installments. Rental finance can reduce the risk associated with the loss or damage to rental assets. ${ }^{14}$

Islamic banks in Indonesia with efforts to optimize the performance of Islamic banks, it must control problem financing (NPF). The lower the NPF, the better the performance of the financing undertaken. ${ }^{15}$ Roziq's research proves that financing risks affect Islamic bank financing performance in East Java. ${ }^{16}$ Based on the background above, the purpose of this study is to find out, test, and prove the effect of financing schemes on risk and financing performance in Islamic banks in Indonesia.

\section{LITERATURE REVIEW Syirkah Theory}

According to Djuwaini, shirkah is a cooperation agreement between two or more parties for a particular business/project in which both parties contribute capital by the agreement that the benefits and

${ }^{14}$ Saleem, S. \& Mansor, F. (2020). Exploring Compliance of AAOIFI Shariah Standard on Ijarah Financing: Analysis on the Practices of Islamic Banks in Malaysia. Journal of Risk and Financial Management, 13(2), (2020), 29.

${ }^{15}$ Sagantha, F, Reviewing the performance of Islamic banks in Indonesia. Scientific Journal Of Reflection, 3(1), (2020), 31-40. doi: 10.5281/zenodo.3597840.

${ }^{16}$ Roziq.2020. Revealing of Financing with Profit Sharing and Islamization of Agency Theory. Jurnal Darussalam; Jurnal Pendidikan, Komunikasi Dan Pemikiran Hukum Islam Vol. XI, No 2:464-478. April 2020. ISSN: $1978-4767$ risks will be borne together by the agreement. ${ }^{17}$ According to ${ }^{18}$ Roziq, the theory of shirkah has been explained in the Qur'an verse Sad verse 24 (Depag, 2005: 650), namely that there are many conflicts between parties who make fellowship (unity) because they commit wrongdoing. Conflict will not occur if the parties to the association run the rules / Islamic union because of faith and good deeds. However, more people commit wrongdoing in the union than those who are trusted. This shirkah theory is very relevant in explaining the relationship between profit-sharing financing consisting of musharaka and mudaraba with financing risks that will occur due to conflicts between parties who conduct shirkah and if the financing is not managed properly.

\section{Exchange Theory}

Exchange theory is a theory relating to social actions that give or exchange objects that contain values between individuals based on a particular social order. Homans exchange theory rests on the assumption that people are involved in behavior to get rewarded or

${ }^{17}$ Djuwaini, Dimyauddin. 2008. Introduction to Figh Muamalah. Cet. 1. Penerbit : Pustaka Pelajar Ctakan 1. Yogyakarta

${ }^{18}$ Ahmad Roziq, The Effect of Islamic Business Ethics on the Performance of Mudharabah Financing through Asymmetrical Information on Islamic Banks in East Java. JEAM, IX(1), (2010), 56-69. 
avoid punishment. This theory based on the principle of economic transactions where people provide goods or services and in return get the desired goods or services. Imbalance in the exchange can occur when giving more rewards to others and vice versa who receive rewards reciprocate. The smallest party in an unbalanced exchange can obtain social approval compensation or refer to as willingness. Willingness in unbalanced exchanges is a credit to superior parties, that is, their position becomes domination so that it is possible to govern others. ${ }^{19}$

\section{Islamic Banking}

According to Banking Law No. 10/1998, banks are business entities that collect and distribute public funds in the form of credit and or other forms to improve the standard of living of the community. The Bank has funding and channeling activities. Islamic banks are financial institutions whose principal business is providing financing and other services in payment traffic and the circulation of money adjusted to Islamic values. In Act Number 10 of 1998 concerning amendment of Law No. 7 of 1992 concerning banking article 1 it is stated that Islamic principles are rules of agreement based on Islamic law between banks and other parties to save and / or finance business activities or other

\footnotetext{
${ }^{19}$ George Ritzer \& J.Goodman

Douglas, Theories of Modern Sociology, (Jakarta : Kencana,2003)
}

activities declared by Islam among others, based on the principle of buying and selling, the principle of profit sharing, and the principle of leasing goods / capital. Islamic finance is the first choice in placing funds in Islamic banking.

\section{Financing Performance}

Helfert defines performance as a result of many individual decisions that are made continuously by management. ${ }^{20}$ Performance is an indicator of a work level because it has given birth to an activity. So, the performance is defined as an achievement achieved by the company in a certain period that reflects the level of health of the company. According to Mulyadi, performance is a periodic determination of the effectiveness of an organization's operations, ${ }^{21}$ organizational sections and employees based on predetermined targets, standards and criteria. ${ }^{22}$ The definition of performance according to the Indonesian dictionary is a noun which means something that is achieved, the achievement shown, and work ability. ${ }^{23}$ Based on the

\footnotetext{
${ }^{20}$ Helfert, E, A., Technique of financial analysis, seventh edition, (Homewood Illionis: Richard D. Irwin Inc, 1991), 56.

${ }^{21}$ Mulyadi. 2001. Balance Scorecard: Contemporary Management Tools For Multipliers of Company Financial Performance. Salemba Empat. Jakarta.

${ }^{22}$ Srimindarti, C., Balanced scorecard as an alternative to measuring performance. http://www.stiestikubank.ac.id/webjurnal.,(2006)

${ }^{23}$ Sucipto, 2013, Measurement of Financial Performance, Jurnal Ekonomi \&
} 
definition of performance, the performance of Islamic banks is measured a lot based on the results that have been achieved such as; comparison of the amount of mudharabah financing with all financing provided by Islamic banks, ${ }^{24}$ return and profit-sharing rate, ${ }^{25}$ growth in total assets and net income. ${ }^{26}$

\section{Risk Of Financing}

One of the risks faced by Islamic banks is the inability of customers to fulfill agreed agreements. The inability of customers to meet obligations to banks results in non-performing financing (NPF). The risk of financing that is accepted by Islamic banks is one of the business risks of the bank, which results from the non-payment of loans. ${ }^{27}$ NonPerforming Financing is a ratio used to measure the ability of bank management in managing existing problematic financing so that it can

Bisnis, FE Universitas Sumatera Utara, Medan.

${ }^{24}$ Yumanita, A. D. (2005). Looking for solutions to low-profit sharing financing in indonesian sharia banking, (Bulletin of Monetary Economics and Banking Jakarta: Bank Indonesia, 2005), 8-50.

${ }^{25}$ Karim, A, Sharia economic optimism, (Jakarta: Republika Online,2004b)

${ }^{26}$ Bashir, Abdel-Hameed M, 1999. Risk and Profitability Measures in Islamic Banks: The Case of Two Sudanese Banks. Journal of Islamic Economic Studies 6 (2):124.

${ }^{27}$ Firmansyah, I., Determinant of non performing loan: the case of islamic bank in indonesia, (Bulletin of Monetary Economics and Banking, 17(2),2015), 241-258. be met with productive assets owned by a bank..$^{28}$ If the portion of problem financing increases, it will ultimately affect the possibility of a decrease in the amount of profit/income obtained by the bank. $\mathrm{NPF}$ is one of the performance appraisal instruments of an Islamic bank which is the interpretation of the valuation of productive assets, especially in the assessment of problem financing.

\section{Financing Scheme}

According to (Muhammad, 2005: 101) ${ }^{29}$ there are two financing methods applied in Islamic banks, namely the non-profit loss sharing method in the form of financing using the sale and purchase system including lease and profit-loss sharing method in the form of financing with the profit and loss sharing system. According to Nizar ${ }^{30}$ states that buying and selling financing consists of murabaha, istishna contracts', and salam contracts. Profit and loss sharing financing is a collaborative agreement between the bank as the

${ }^{28}$ Yudha, Profit-sharing financing, sale and purchase financing and financing risk and profit margin at sharia banks, (National Seminars and Call Papers: Management, Accounting, and Banking, 2018), 1090-1104.

${ }^{29}$ Muhammad. (2005). Management of Sharia Bank. Unit Penerbit dan Percetakan (UPP) AMP YKPN. Yogyakarta

${ }^{30}$ Nizar, A. S., Musharka Financing for Poverty Alleviation in Pakistan. International Letters of Social and Humanistic Sciences, 37(January), (2015), 71-81. 
owner of capital and the customer as the manager of capital to obtain profits and share the profits obtained based on agreed agreements Yudha. ${ }^{31}$ The profitsharing system consists of mudaraba and musyaraka contracts. Mudaraba financing is a funding agreement from the owner of the fund (shahibul maal) to the fund manager (mudharib) to carry out certain business activities by Islam, with the distribution of business results between the two parties based on a predetermined ratio (OJK, 2019). Whereas, musyaraka financing is a financing agreement of two or more owners of funds and/or goods to carry out certain business by Islam with the distribution of business results between the two parties based on an agreed ratio, while the distribution of losses is based on the proportion of each capital. ${ }^{32}$ According to Muhammad, ${ }^{33}$ lease financing is a lease transaction of goods and/or services between the owner of the leased object, including ownership of the right to use the lease object and the lessee to get compensation for the object of the leased object.

\footnotetext{
${ }^{31}$ Yudha, Profit-sharing financing, sale and purchase financing and financing risk and profit margin at sharia banks. National Seminars and Call Papers: Management, Accounting, and Banking 2018, (2018), 1090-1104.

${ }^{32}$ OJK .(2019). Sharia Banking Statistics as of November 2019

${ }^{33}$ Muhammad, Islamic Banking: Ijarah and Conventional Leasing. Developing Country Studies, 4(9), (2014), 126-130.
}

Ijarah means the transfer of use rights from goods or services followed by payment of wages or rental fees without being accompanied by a transfer of ownership. ${ }^{34}$

\section{CONCEPTUAL FRAMEWORK AND RESEARCH}

Based on the theoretical basis and a review of previous research described above, the conceptual framework of this study is described as follows:

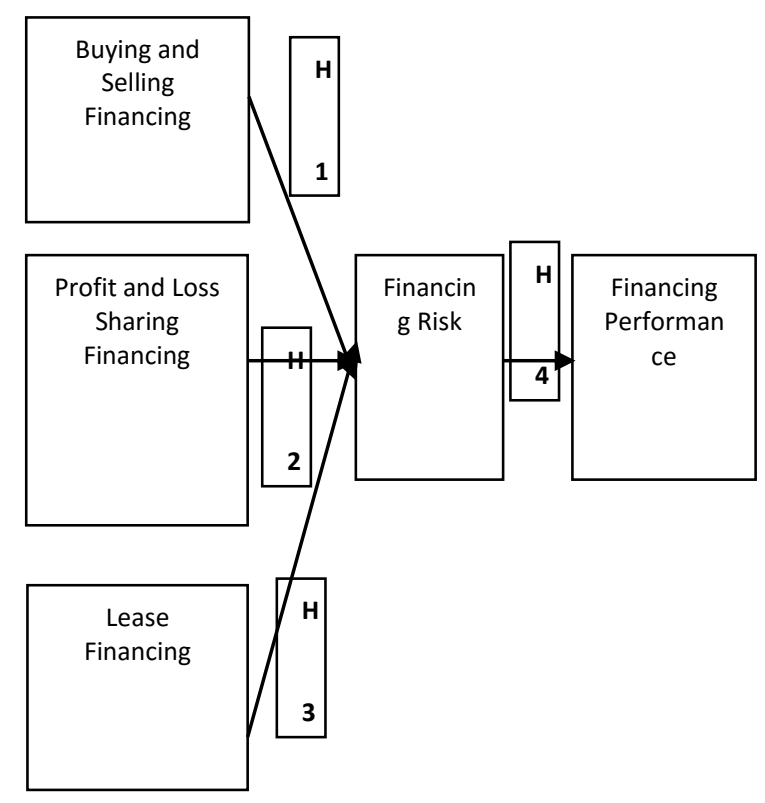

Figure 1. Research Conceptual Framework

Based on the study of theory and previous research and the conceptual framework of the above research, the hypothesis in this research are as follow;

\footnotetext{
${ }^{34}$ Nurhayati, S., \& Wasilah. (2013). Sharia Accounting in Indonesia, Edition 3. Salemba Empat.
} 
H1: Buying and selling financing has a significant effect on Financing risk

H2: Profit and loss sharing financing has a significant effect on financing risk

H3: Lease financing has a significant effect on financing risk

H4: Financing risk has a significant effect on financing performance

\section{RESEARCH METHODS}

This study applies a quantitative form of research to the type of explanatory research that aims to explain, test, and prove a theory or hypothesis to accept or reject the theory or hypothesis of existing research results. The type of data in this research is secondary data in the form of Islamic banking financial statements for 2014-2018. The data source used in this study comes from the publication of Islamic banking financial reports obtained through the official websites of each Islamic banking and information related to research through the Financial Services Authority website.

The population in this study is Islamic Banking in Indonesia as many as 14 Islamic banks in the 2014-2018 period. The sample is part of the population that is considered to represent its characteristics. In this study using purposive sampling. Sugiyono revealed that purposive sampling is one technique in taking samples with certain considerations. ${ }^{35}$ The sample taken must be representative, meaning that all population characteristics are reflected in the selected sample. This study uses a purposive sampling method with the following criteria: (a) Islamic banks starting from 2014-2018; (b) Islamic banks which published financial statements in the 2014-2018 period and (c) there are complete data needed in research starting from 2014-2018.

This study uses data collection techniques in the form of documentation, namely by collecting, recording, and studying secondary data in the form of audited financial statements from Islamic banking in 2014-2018. This study uses the dependent variable, namely financial performance, intervening variables, namely risk financing and the independent variable, namely financing schemes consisting of buying and selling financing, profit and loss sharing financing, and lease financing.

The researcher uses the path diagram and structural equation by making a path diagram to present the problem in the form of a picture and determine the structural equation that states the relationship between these variables. This study uses the SmartPLS basis is a powerful analysis method. ${ }^{36}$ PLS is

\footnotetext{
${ }^{35}$ Sugiyono. (2016). Method of Quantitative-Qualitative Research and RED. Bandung: PT Alfabet

${ }^{36}$ Ghozali, I., Partial least squares (concepts, techniques, and applications using the smartpls 3.0 edition 2 program) Semarang:
} 
often referred to as soft modeling because it excludes assumptions such as data that must be normally distributed multivariate and there is no multicollinearity problem between exogenous variables. PLS is used to test weak theories and small sample data or problems with data normality. Although PLS is used to explain the presence or absence of relationships between latent variables, PLS can also be used to confirm theories. So, PLS aims to predict theory. ${ }^{37}$

\section{RESEARCH DISCUSSION}

This study uses the SmartPLS basis is a powerful analysis method. ${ }^{38}$ The purpose of PLS is to predict theories. PLS analysis consists of two sub-models, namely the measurement model (outer model) and the structural model (inner model). The following are the results by data using SmartPLS output which includes the results of validity test, reliability test, inner model, inner weight for hypothesis testing, and goodness-fit model test. The measurement model shows the manifest variable represents the measured variable. While the structural model shows the estimated power between variables.

\footnotetext{
Badan Penerbit Undip,2019)

${ }^{37}$ Ghozali, I., Partial least squares (concepts, techniques, and applications using the smartpls 3.0 edition 2 program) Semarang: Badan Penerbit Undip,2019)

${ }^{38}$ Ghozali, I., Partial least squares (concepts, techniques, and applications using the smartpls 3.0 edition 2 program) Semarang: Badan Penerbit Undip,2019)
}

Validity test with the SmartPLS program can be seen from the loading factor value for each construct indicator $>0.7$ for confirmatory research and the loading factor value between 0.6 0.7 for explanatory research is still acceptable and the average variance extracted (AVE) value must be more than $>0.5 .{ }^{39}$ Based on this, the variable of buying and selling financing, profit and loss sharing financing, lease financing, and financing risk meet the contract validity because it gets a scale of $>$ 0.7 (see Table 1).

Reliability tests are carried out to prove the accuracy, consistency, and accuracy of the instrument in measuring constructs. The PLS program is used to measure reliability with reflexive indicators in two ways, namely Cronbach's Alpha and Composite Reliability. However, Cronbach's Alpha tests the reliability of the contract by giving a value that is more render (underestimate) so it is advisable to use Composite Reliability. Composite Reliability value must be more than $>0.7$ for confirmatory research while for explanatory research the value 0.6 0.7 is still accepted. Composite Reliability is called DillonGoldstein's which is calculated using a formula developed by Werts, Linn, and Joreskog (1974) to

${ }^{39}$ Ghozali, I., Partial least squares (concepts, techniques, and applications using the smartpls 3.0 edition 2 program) Semarang: Badan Penerbit Undip,2019) 
measure internal consistency as follows. ${ }^{40}$

Table 1. Reliability

\begin{tabular}{l|c|c|c|}
\hline & $\begin{array}{c}\text { Cronbach's } \\
\text { Alpha }\end{array}$ & $\begin{array}{c}\text { Composite } \\
\text { Reliability }\end{array}$ & $\begin{array}{c}\text { Average } \\
\text { Variance } \\
\text { Extracted } \\
\text { (AVE) }\end{array}$ \\
\hline $\begin{array}{l}\text { Buying and } \\
\text { selling } \\
\text { financing }\end{array}$ & 1.000 & 1.000 & 1.000 \\
\hline $\begin{array}{l}\text { Profit and } \\
\text { loss sharing } \\
\text { financing }\end{array}$ & 1.000 & 1.000 & 1.000 \\
\hline $\begin{array}{l}\text { Lease } \\
\text { financing }\end{array}$ & 1.000 & 1.000 & 1.000 \\
\hline $\begin{array}{l}\text { Financing } \\
\text { risk }\end{array}$ & 1.000 & 1.000 & 1.000 \\
\hline $\begin{array}{l}\text { Financing } \\
\text { performance }\end{array}$ & 1.000 & 1.000 & 1.000 \\
\hline
\end{tabular}

Source: SmartPLS output

Based on smartPLS output all constructs have composite reliability values and Cronbach's alpha values above 0.7 (see table 1.). So it can be concluded that the construct has good reliability. Assessing the reliability of a construct can be done by looking at the Average Variance Extracted (AVE) showing the value of AVE> 0.5 means having high 1. $1 \cdot 1 \cdot 1$

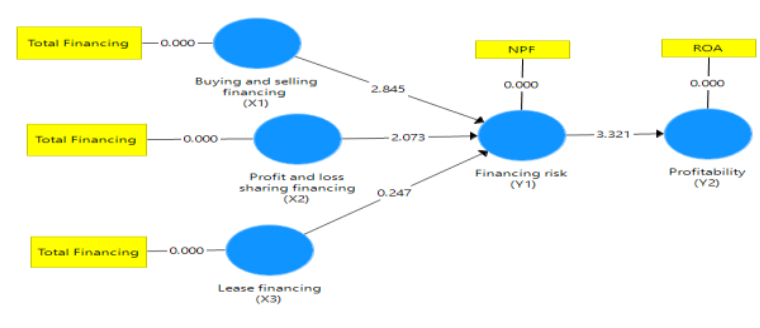

${ }^{40}$ Ghozali, I., Partial least squares (concepts, techniques, and applications using the smartpls 3.0 edition 2 program) Semarang: Badan Penerbit Undip,2019)
Figure2. Inner Model

Testing of the structural model is also carried out by looking at the significance of the influence of the financing scheme variables on the financing risk variable and the effect of the financing risk variable on the financing performance variable by looking at the parameter coefficient and the significance value of $t$ statistics (see table 1). Based on the results of path analysis using SmartPLS (see table 1), first finding of the of research show that variable of buying and selling financing has a negative significant effect on financing risk variable with a coefficient of -0.120 and significant with a statistical $\mathrm{T}$ of 2.804 greater than T-table of 1.94. The first hypothesis in this study is that buying and selling financing affects the risk of financing, so $\mathrm{H} 1$ is accepted. Second finding of the results show that variable of profit and loss sharing financing has a significant negative effect on financing risks with a coefficient of 0.146 and significant with a statistical $\mathrm{T}$ of 1.994 greater than $\mathrm{T}$ table of 1.94. The second hypothesis in this study is the variable of profit and loss sharing affects the risk of financing, so H2 is accepted. Third finding of the results show that variable of lease financing has no significant effect on financing risks with a coefficient of 0.028 and significant with a statistical $\mathrm{T}$ of 0.243 smaller than T-table of 1.94 . The third hypothesis in this study is lease financing affects the risk of 
financing, so H3 is rejected. And fourth finding of the results are that the variable of financing risk has a significant positive effect on financing performance with a coefficient of 0.466 and significant with a statistical $\mathrm{T}$ of 3.298 greater than T-table 1.94. The fourth hypothesis in this study is that financing risk influences financing performance, so $\mathrm{H} 4$ is accepted.

Table 2. Inner Weight

\begin{tabular}{l|c|c|c|c|c}
\hline & $\begin{array}{c}\text { Original } \\
\text { Sample }\end{array}$ & $\begin{array}{c}\text { Sample } \\
\text { Mean }\end{array}$ & $\begin{array}{c}\text { Standard } \\
\text { Deviation }\end{array}$ & $\begin{array}{c}\text { T- } \\
\text { Statistic }\end{array}$ & Significance \\
\hline $\begin{array}{l}\text { Buying and } \\
\text { selling } \\
\text { financing } \\
\begin{array}{l}\text { Financing } \\
\text { risk }\end{array}\end{array}$ & -0.120 & -0.130 & 0.043 & 2.804 & Significant \\
\hline $\begin{array}{l}\text { Profit and } \\
\text { loss sharing } \\
\text { financing }\end{array}$ & -0.146 & -0.156 & 0.073 & 1.994 & Significant \\
$\begin{array}{l}\text { Financing } \\
\text { risk }\end{array}$ & & & & & \\
\hline $\begin{array}{l}\text { Lease } \\
\text { financing }\end{array}$ & 0.028 & 0.040 & 0.116 & 0.243 & $\begin{array}{c}\text { Non- } \\
\begin{array}{l}\text { Financing } \\
\text { risk }\end{array}\end{array}$ \\
\hline $\begin{array}{l}\text { Financing } \\
\text { risk }\end{array}$ & 0.466 & 0.474 & 0.141 & 3.298 & Significant \\
$\begin{array}{l}\text { Financing } \\
\text { Performance }\end{array}$ & & & & & \\
\hline
\end{tabular}

Source: SmartPLS output

Testing of structural models is done by looking at the R-square value which is a goodness-fit test of the model. From table 3, it is known that the model of the influence of buying and selling financing, profit and loss sharing financing and lease financing to variable of financing risk gives an R-square value of 0.217 which can be interpreted that the variability of financing risk can be explained by the variability of the sale and purchase financing scheme, profit sharing and rent by $21,7 \%$ while $78.3 \%$ is explained by other variables outside the study.

Tabel 3. R-Square

\begin{tabular}{c|c}
\hline & R-Square \\
\hline Financing Risk & 0.217 \\
\hline
\end{tabular}

\begin{tabular}{c|c}
\hline Financing Performance & 0.390 \\
\hline \multicolumn{2}{c}{ Source: SmartPLS Report }
\end{tabular}

The model of the influence of the variable of buying ans selling financing, profit and loss sharing financing, lease financing and financing risk variable on financing performance provides an R-square value of 0.390 which can be interpreted that the variability of financing performance can be explained by the variability of the buying ans selling financing, profit and loss sharing financing, lease financing and financing risk variable by $39 \%$ while $61 \%$ is explained by other variables outside the study such as the operational expense-operating income variable, efficiency, capital structure, governance, and other variables. The findings of this study can be used by future researchers to develop this research by adding the operational expense-operating income variable, efficiency, capital structure, governance, and other variables to the research model.

Based on the results of path analysis using SmartPLS, it is obtained that the buying and selling financing affects the risk of financing, so H1 is accepted. The results of this study support the theory explained by (Darwin ${ }^{41}$ and

${ }^{41}$ Darwin. (2020). The process of risk management implementation in murabaha financing at bprs hajj poor pandai sikek tanah datar district, provinsi sumatera barat. Journal of Economics, Finance, Investment, and Sharia (EKUITAS), 1(2), (2020), 100-110. 
Muhammad ${ }^{42}$ ) that financing risks can have a positive or negative effect depending on the information asymmetry that occurs in banking operational activities. Financing risk occurs if the bank does not get an installment on the loan given. The results of this study support the research findings of Afif and Mawardi, ${ }^{43}$ Sholihah, ${ }^{44}$ Mukhibad and Khafid, ${ }^{45}$ Darwin $^{46}$ finding that buying and selling financing has a significant effect on risk Islamic financing. High funding will greatly affect the risk of uncollectible financing. Banks will experience difficulty in liability if there is a high risk of financing.

Based on the results of path analysis using SmartPLS, the results

\footnotetext{
${ }^{42}$ Muhammad, Management of Sharia Bank, (Yogyakarta: UPP Sekolah Tinggi Manajemen YKPN, 2011)

${ }^{43}$ Afif \& Mawardi, (2014). Effect of Murabahah Financing Against Profit Through Intervening Variable Problematic Financing of Sharia Commercial Banks in Indonesia Period 2009-2013, Jestt, 1(8), pp. 565-580

${ }^{44}$ Sholihah. (2013). Analysis of the influence of inflation, GDP, financing deposit ratio, and return of profit and loss sharing financing against non-performing financing in sharia banking in indonesia. Thesis. UIN Sunan Kalijaga.

${ }^{45}$ Mukhibad, H. \& Khafid, M. (2018). Article history: Financial Performance Determinant of Islamic Banking in Indonesia. Journal of Finance and Banking 22(3), pp. 506-517.

${ }^{46}$ Darwin. (2020). The process of risk management implementation in murabaha financing at bprs hajj poor pandai sikek tanah datar district, provinsi sumatera barat. Journal of Economics, Finance, Investment, and Sharia (EKUITAS), 1(2), pp. 100-110.
}

show that the financing of profit and loss sharing affects the risk of financing, so $\mathrm{H} 2$ is accepted. The results of this study support the theory explained by Arfan $^{47}$ and Sabrina, ${ }^{48}$ that Islamic banking is minimal in openness to financial statements, whereas openness is an important principle for preventing fraud. This condition will trigger information asymmetry. Profitsharing based financing is caused by six factors, namely high risk, lack of quality and human resources, complicated handling, no product innovation, information asymmetry, and lack of socialization. The results of this study support the research findings of Djatmiko and Rachman, ${ }^{49}$ Kusumawati, ${ }^{50}$ Yudha, ${ }^{51}$

${ }^{47}$ Arfan, A., Saifullah, \& Fakhruddin. (2016). Implementation of principles for profit sharing and risk management in financing products. Journal of Religious Social Research 214, 10(1), pp. 213-238.

${ }^{48}$ Sabrina \& Majid, M. S. A. (2019). Why is financing based on low-profit sharing in Islamic banking? (A Study Using a Grounded Theory Approach). Scientific Journal of Islamic Economics Students, 1(1), pp. 51-70.

${ }^{49}$ Rachman, D. (2015). Effect of Mudharabah and Murabahah Financing on Non-Performing Financing (NPF) (Case Study of Sharia Commercial Banks in Indonesia). Study and Accounting research, XII(1), pp. 19-38.

${ }^{50}$ Kusumawati, R. (2010). The Effect of Leadership Characteristics and New Product Innovation on Company Performance to Achieve Sustainable Competitive Advantage, AKSES: Journal of Economics and Business, 5(9), pp. 53-64.

${ }^{51}$ Yudha. (2018). Profit-sharing financing, sale and purchase financing and financing risk and profit margin at sharia 
and Sabrina ${ }^{52}$ finding that profit and loss sharing financing affects financing risk.

Based on the results of the path analysis using SmartPLS, the results show that lease financing does not influence the risk of financing, so $\mathrm{H} 3$ is rejected. The results of this study do not support the theory explained by Rustam, ${ }^{53}$ and Kurnia ${ }^{54}$ that Islamic banks need to consider the risks of lease failure in meeting installment payment obligations. The risk arising from the lease contract is caused if the bank's belongings arise unproductive risk. Non-bank goods arise the risk of damage to goods by customers due to abnormal usage. If in the case of manpower services directed by the bank, then the customer risks the quality of the service provider which may not be as expected. The results of this study do not support research findings from Lestari, ${ }^{55}$ Wulansari, ${ }^{56}$

banks. National Seminars and Call Papers: Management, Accounting, and Banking 2018, pp. 1090-1104.

${ }^{52}$ Sabrina \& Majid, M. S. A. (2019). Why is financing based on low-profit sharing in Islamic banking? (A Study Using a Grounded Theory Approach). Scientific Journal of Islamic Economics Students, 1(1), pp. 51-70.

${ }^{53}$ Rustam, B. R. (2013). Sharia

Banking Risk Management in Indonesia.

Jakarta: Salemba Empat.

${ }^{54}$ Kurnia, R. A. E., Sawarjuwono, T. \& Herianingrum, S. (2017). Financing risk management to anticipate financial distress conditions in Islamic banks. Journal of Islamic Economics Lariba, 3(2), pp. 51-64.

${ }^{55}$ Lestari. (2017). Risk of Financing in Istishna Covenant at Islamic Commercial Banks. Journal of Adzkiya, Vol 2, No 1.
Saleem $^{57}$ proving that lease financing has a significant effect on financing risk.

Based on the results of path analysis using SmartPLS, the results are that the financing risk influences financing performance, so $\mathrm{H} 4$ is accepted. The results of this study do not support the theory explained by Firmansyah ${ }^{58}$ that NPF is very influential on cost control and at the same time also affects the performance of financing policies to be carried out by banks. Agency theory has a role to reduce the risk that occurs between shahibul maal and mudarib. The financing performance will not be separated from the financing risks faced by Islamic banks. The smaller the financing risk faced, the better the performance of the banking financing. This study supports research findings from Firmansyah, ${ }^{59}$ Kurniawansyah $^{60}$ that

\footnotetext{
${ }^{56}$ Wulansari. (2019). Risk management of ijarah financing against customer financing returns (case study: BMT dana mentari muhammadiyah pasar pon). Skripsi, IAIN Purwokerto.

${ }^{57}$ Saleem, S. \& Mansor, F. (2020). Exploring Compliance of AAOIFI Shariah Standard on Ijarah Financing: Analysis on the Practices of Islamic Banks in Malaysia. Journal of Risk and Financial Management, 13(2), p. 29.

${ }^{58}$ Firmansyah, I. (2015). Determinant of non performing loan: the case of islamic bank in indonesia. Bulletin of Monetary Economics and Banking, 17(2), pp. 241-258.

${ }^{59}$ Firmansyah, I. (2015). Determinant of non performing loan: the case of islamic bank in indonesia. Bulletin of Monetary Economics and Banking, 17(2), pp. 241-258.
} 
financing risk affects financing performance.

\section{CONCLUSION}

Based on the results of research and discussion it can be concluded that the buying sale and purchase financing affects the risk of financing. The first hypothesis in this study is that buying and selling financing affects the risk of financing, so H1 is accepted. Profit and loss sharing financing affects the risk of financing. The second hypothesis in this study is the financing of profit and loss sharing affects the risk of financing, so $\mathrm{H} 2$ is accepted. Lease financing does not affect financing risk. The third hypothesis in this study is lease financing affects the risk of financing, so H3 is rejected. The risk of financing has a significant effect on the financing performance in Islamic banks in Indonesia. The fourth hypothesis in this study is that the risk of financing has a significant effect on financing performance so that $\mathrm{H} 4$ is accepted. Based on the results of research and discussion, it can be suggested that the management of Islamic banks must be able to control the financing of buying and selling and profit and loss sharing financing to be able to minimize the risk of financing by managing the buying and selling

\footnotetext{
${ }^{60}$ Kurniawansyah, D. (2016). Profit Loss Sharing Funding and Financing of the Sharia Commercial Bank Profitability in Indonesia with Efficiency and Risk as Mediation. Journal of Accounting and Finance 18(1), pp. 1-26.
}

financing schemes and profit and loss sharing with good and right governance and caution. So in this way, the management of Islamic can minimize the risk of financing. When financing risks can be minimized, management will be able to improve the performance of Islamic bank financing. Future researchers can develop the results of this study by adding the operational expense-operating income variable, efficiency, capital structure, governance, and other variables to the research model..

\section{REFERENCES}

Amalia, S., \& Hapsari, A. A. 2009. Credit risk analysis based on mudharabah and musyarakah profit sharing funds based on profitability (ROA) of sharia foreign exchange commercial banks per quarter (2016-2017 period). ISEI Accounting Review, I (1), pp. 32-38.

Arfan, A., Saifullah, \& Fakhruddin. 2016. Implementation of principles for profit sharing and risk management in financing products. Journal of Religious Social Research 214, 10(1), pp. 213-238.

Bashir, Abdel-Hameed M. 1999. Risk and Profitability Measures in Islamic Banks: The Case of Two Sudanese Banks. Journal of Islamic Economic Studies 6 (2):1-24

Darwin. 2020. The process of risk management implementation in murabaha financing at bprs hajj poor pandai sikek tanah datar district, provinsi sumatera barat. 
Journal of Economics, Finance, Investment, and Sharia (EKUITAS), 1(2), pp. 100-110.

Dayu, P. Q. 2015. Effect of capital adequacy level, liquidity, market risk, and credit risk on financial performance in conventional banks. E-Jurnal Universitas Negeri Padang, pp. 1-15.

Djuwaini, Dimyauddin. 2008. Introduction to Figh Muamalah. Cet. 1. Penerbit : Pustaka Pelajar Ctakan 1. Yogyakarta

Farida, \& Dewi, F. 2016. The analysis of risk management on syariah banking in indonesia. Seminar Nasional dan The 3rd Call for Syariah Paper. 1. 164-174.

Firmansyah, I. 2015. Determinant of non performing loan: the case of islamic bank in indonesia. Bulletin of Monetary Economics and Banking, 17(2), pp. 241-258.

Ghozali, I. 2019. Partial least squares (concepts, techniques, and applications using the smartpls 3.0 edition 2 program). Badan Penerbit Undip, Semarang.

Hafidh, A. A. 2011. Analisis hubungan pengeluaran pendidikan dan pertumbuhan ekonomi dengan menggunakan pendekatan kausalitas granger. Journal of Economics \& Education, 8 (November), pp. 124-141.

Harahap, A. S., \& Siregar, S. 2020. Operational risk of islamic banking murabahah financing. National Seminar on Computer Technology and Science pp. 561-567.

Helfert, E, A. 1991. Technique of financial analysis, seventh edition, Homewood Illionis: Richard D. Irwin Inc.

Jensen, M. C. \& Meckling, W. H. 1976. Theory of the firm: managerial. Journal of Financial Economics, 3, pp. 305-360.

Karim, A. 2004a. Islamic bank: figh and financial analysis, second edition, Jakarta: PT. Raja Grafindo Persada.

2004b. Sharia economic optimism. Jakarta: Republika Online.

Kurnia, R. A. E., Sawarjuwono, T. \& Herianingrum, S. 2017. Financing risk management to anticipate financial distress conditions in Islamic banks. Journal of Islamic Economics Lariba, 3(2), pp. 51-64.

Kurniawansyah, D. 2016. Profit Loss Sharing Funding and Financing of the Sharia Commercial Bank Profitability in Indonesia with Efficiency and Risk as Mediation. Journal of Accounting and Finance 18(1), pp. 1-26.

Kusumawati, R. 2010. The Effect of Leadership Characteristics and New Product Innovation on Company Performance to Achieve Sustainable Competitive Advantage, AKSES: Journal of Economics and Business, 5(9), pp. 53-64.

Lestari. 2017. Risk of Financing in Istishna Covenant at Islamic Commercial Banks. Journal of Adzkiya, Vol 2, No 1.

Mawardi, A. 2014. Effect of Murabahah Financing Against Profit Through Intervening Variable Problematic Financing of Sharia Commercial Banks in Indonesia Period 2009-2013, Jestt, 1(8), pp. 
$565-580$.

Muhammad. 2002. Sharia Bank: Strength, Weakness, Opportunity, and Threat Analysis, Second Edition, Yogyakarta: Ekonesia Faculty of Economics UII.

. 2005. Management of Sharia

Bank. Unit Penerbit dan

Percetakan (UPP) AMP YKPN.

Yogyakarta

. 2011. Management of Sharia

Bank. Yogyakarta: UPP

Sekolah Tinggi Manajemen

YKPN

. 2014. Islamic Banking: Ijarah and Conventional Leasing.

Developing Country Studies, 4(9), pp. 126-130.

Mukhibad, H. \& Khafid, M. 2018. Article history: Financial Performance Determinant of Islamic Banking in Indonesia. Journal of Finance and Banking 22(3), pp. 506-517.

Mulyadi. 2001. Balance Scorecard:

Contemporary Management Tools

For Multipliers

of Company Financial

Performance. Salemba Empat. Jakarta.

Nizar, A. S. 2015. Musharka Financing for Poverty Alleviation in Pakistan. International Letters of Social and Humanistic Sciences, 37(January), pp. 7181.

Nurhayati, S., \& Wasilah. 2013. Sharia Accounting in Indonesia, Edition 3. Salemba Empat.

OJK. 2018. Indonesia Sharia Financial Development Report, pp. 1-106. 2019. Sharia Banking Statistics as of November 2019

Rachman, D. 2015. Effect of
Mudharabah and Murabahah Financing on Non-Performing Financing (NPF) (Case Study of Sharia Commercial Banks in Indonesia). Study and Accounting research, XII(1), pp. 19-38.

Ritzer, George \& Douglas J.Goodman. 2003. Theories of Modern Sociology. Jakarta : Kencana

Roziq, A. 2010. The Effect of Islamic Business Ethics on the Performance of Mudharabah Financing through Asymmetrical Information on Islamic Banks in East Java. JEAM, IX(1), pp. 5669.

Roziq. 2020. Revealing of Financing with Profit Sharing and Islamization of Agency Theory. Jurnal Darussalam; Jurnal Pendidikan, Komunikasi Dan Pemikiran Hukum Islam Vol. XI, No 2:464-478. April 2020. ISSN: 1978-4767.

Rustam, B. R. 2013. Sharia Banking Risk Management in Indonesia. Jakarta: Salemba Empat.

Sabrina \& Majid, M. S. A. 2019. Why is financing based on low-profit sharing in Islamic banking? (A Study Using a Grounded Theory Approach). Scientific Journal of Islamic Economics Students, $1(1)$, pp. 51-70.

Sagantha, F. 2020. Reviewing the performance of Islamic banks in Indonesia. Scientific Journal Of Reflection, 3(1), pp. 31-40. doi: 10.5281/zenodo.3597840.

Saleem, S. \& Mansor, F. 2020. Exploring Compliance of AAOIFI Shariah Standard on Ijarah Financing: Analysis on the 
Practices of Islamic Banks in Malaysia. Journal of Risk and Financial Management, 13(2), p. 29.

Sari, D. W. \& Anshori, M. Y. 2018. Effect of Murabahah, Istishna, Mudharabah, and Musyarakah Financing on Profitability (Study of Sharia Banks in Indonesia Period March 2015 - August 2016). Accounting and Management Journal, 1(1), pp. 1-8.

Sholihah. 2013. Analysis of the influence of inflation, GDP, financing deposit ratio, and return of profit and loss sharing financing against non-performing financing in sharia banking in indonesia. Thesis. UIN Sunan Kalijaga.

Srimindarti, C. 2006. Balanced scorecard as an alternative to measuring performance. http://www.stiestikubank.ac.id/webjurnal.

Sucipto. 2013. Measurement of Financial Performance, Jurnal Ekonomi \& Bisnis, FE Universitas Sumatera Utara, Medan.

Sugiyono. 2016. Method of Quantitative -Qualitative Research and RED. Bandung: PT Alfabet.

Susanti, S. \& Azis, Y. M. 2018. Satisfaction drivers in sharia banking: comparison PLS-SEM and CB-SEM. International
Journal of Research Publications, 10(1), pp. 1-10.

Waldelmi, I. \& Masirun. 2018. Analysis of factors affecting consumer's behavior on syariah Banking Products. IOP Conference Series: Earth and Environmental Science, 175(1).

Wold, H. 1974. Causal flows with latent variables. Partings of the ways in the light of NIPALS modelling. European Economic Review, 5(1), pp. 67-86.

Wulansari. 2019. Risk management of ijarah financing against customer financing returns (case study: BMT dana mentari muhammadiyah pasar pon). Skripsi, IAIN Purwokerto.

Yudha. 2018. Profit-sharing financing, sale and purchase financing and financing risk and profit margin at sharia banks. National Seminars and Call Papers: Management, Accounting, and Banking 2018, pp. 1090-1104.

Yumanita, A. D. 2005. Looking for solutions to low-profit sharing financing in indonesian sharia banking. Bulletin of Monetary Economics and Banking : 8-50. Jakarta: Bank Indonesia 